ORIGINAL ARTICLE

\title{
Indices of asthma among atopic and non-atopic woodworkers
}

\author{
V Schlünssen, I Schaumburg, D Heederik, E Taudorf, T Sigsgaard
}

Occup Environ Med 2004;61:504-511. doi: 10.1136/oem.2003.007815

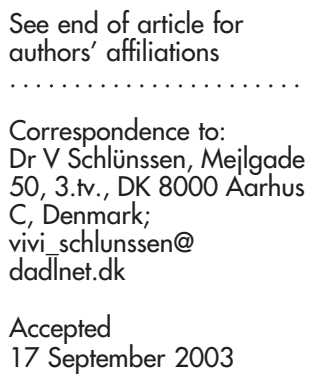

...................

\begin{abstract}
Aims: To investigate the relation between wood dust exposure and different indices of asthma among woodworkers and non-exposed subjects.

Methods: A total of 302 woodworkers and 71 non-exposed subjects answered a respiratory health questionnaire, underwent a non-specific bronchial provocation test using the Yan method, and received a skin prick test with 12 common inhalant allergens. Subgroups performed repeated peak flow monitoring and underwent a reversibility test. A total of 347 dust measurements among 234 woodworkers were performed with passive dust monitors.

Results: The overall geometric mean (geometric standard deviation) exposure to inhalable dust was 0.96 (2.02) $\mathrm{mg} / \mathrm{m}^{3}$. There was a tendency to increased risk of asthma among atopic woodworkers compared to atopic non-exposed subjects, with ORs between 3.0 (0.8-11.9) (symptomatic BHR) and 1.3 (0.5-4.2) (work related symptoms). In woodworkers, asthma was associated with atopy, with ORs between 7.4 (2.8-19.7) (symptomatic BHR) and 4.2 (2.4-7.7) (asthma symptoms). Asthma was related to dust level, most pronounced for symptomatic BHR among atopics, with OR 22.9 (1.0-523.6) for the highest compared to the lowest dust level. For work related asthma symptoms the association with dust level was seen only for non-atopics.

Conclusions: Wood dust exposure was associated with asthma, despite a low dust level compared to other studies. Atopy was an important effect modifier in the association between asthma and wood dust exposure.
\end{abstract}

A t least two million workers in the European Union are employed in the wood industry. ${ }^{1}$ The association between exposure to wood dust and asthmatic symptoms has been known for a long time. ${ }^{2}$ Results from cross sectional epidemiological studies indicate that workers exposed to wood dust have an increased risk of suffering from asthma symptoms with odds ratios (ORs) between 1 and $9 .{ }^{3-10}$ Furthermore, reduced lung function levels indicative of obstruction $\left(\mathrm{FEV}_{1}, \mathrm{FEV}_{\mathrm{l}} / \mathrm{FVC}\right)$ are reported among wood dust exposed workers. ${ }^{611}$ With the exception of western red cedar, only few studies have shown a dose-response relation between wood dust exposure and lung function or asthma symptoms. ${ }^{5} 611$

Exposure to dust from certain kinds of wood, such as western red cedar, oak, iroko, abachi, and mahogany can cause asthma. ${ }^{12}{ }^{13}$ The pathophysiological mechanism responsible for the effect of wood dust is unclear. With the exception of western red cedar, knowledge about asthma and wood dust relies heavily on case reports.

In general, exposure assessment in the furniture industry is either based on studies of contemporary exposure, which was not an integrated part of the epidemiological study, or based on qualitative data supplemented by a limited number of measurements. Furthermore, most previous studies have been characterised by small study populations, where confounding variables such as smoking and atopy could not be dealt with appropriately. In order to assess exposure, quantitative methods are preferable, but costly. The introduction of a passive dust monitor makes it economically feasible to perform a large number of personal measurements. ${ }^{14} 15$

Currently, an epidemiological follow up study is been undertaken in Viborg County, Denmark, in order to investigate the relation between wood dust exposure and non-malignant respiratory diseases. The cross sectional part of the study including dust exposure measurements was performed in 1997-98. ${ }^{16}$ Clinical investigations among a subgroup of the population were performed in 1998-99. The aim of this part of the study was to investigate the relation between wood dust exposure and different indices of asthma.

\section{MATERIAL AND METHODS \\ Study design}

The study design is described elsewhere, ${ }^{16}$ but in brief, one hundred furniture factories situated in Viborg County were identified. Factories with more than 20 employees were asked to participate (45 of 48 accepted), and additionally a random sample of factories with 5-20 employees participated (9 of 38). Thus, a total of 54 furniture factories participated in the study; the base study population was defined as all workers employed in wood working departments, assembly departments, and stock departments of these factories. Furthermore, three control factories (two producing refrigerators, one producing hearing aids) were selected. Control subjects were chosen, where only mechanical assembly was performed, and no exposure to any known sensitiser was observed.

Modified American Thoracic Society questionnaires ${ }^{17}$ with additional questions on allergy, asthma, rhinitis, smoking, and an occupational history including specific tasks were handed out in the factories. In total 2033 woodworkers (88\%) and 474 non-exposed subjects $(82 \%)$ returned the questionnaire.

Abbreviations: BDIR, bronchodilator induced reversibility; BHR, bronchial hyperresponsive; FEV, forced expiratory volume; GAM, general additive models; GM, geometric mean; GSD, geometric standard deviation; OR, odds ratio; PEF, peak expiratory flow; RR, relative risk 
Main messages

- Wood dust exposure is associated with asthma, despite a low dust level.

- Atopy is a significant effect modifier in the association between asthma and wood dust exposure.

A nested case-referent design was achieved for the clinical part of the study. Based on results from the questionnaire survey, a random sample, stratified by asthma symptom status was invited for the clinical investigations; 373 subjects accepted (participation rate $74 \%$ ). Figure 1 shows a flow chart of the investigation. In order to investigate subgroups of subjects with indices of asthma, twice as many subjects with asthma symptoms compared to subjects with no asthma symptoms were invited. A power calculation was done prior to the study, ${ }^{18}$ and with this population size RRs in an order of magnitude of 2 could be detected for symptoms with an assumed prevalence between $5 \%$ and $10 \%$. There was a $2-18$ month time lag between the exposure assessment and the clinical examination.

\section{Occupational hygiene survey}

Personal dust sampling was carried out with passive dust monitors as described earlier. ${ }^{14}{ }^{15}$ The method is based on measuring light extinction before and after sampling on transparent foils. The light extinction increase was reported as dust covered foil area, converted into equivalent inhalable dust concentration by linear regression models, based on earlier and present calibration measurements. ${ }^{15}$

A total of 234 woodworkers attending the clinical investigation had between one and three dust measurements, a total of 347 measurements. The arithmetic mean for each person was used in the exposure assessment.

A job exposure matrix based on task and factory size ( 12 groups) was used (Schlünssen et al, conditionally accepted) to assign exposure to 61 woodworkers, for whom no measurements were available. For seven woodworkers no exposure data were available.

In further analyses, 295 (234+61) woodworkers were divided into four groups based on the quartiles of the distribution of the dust exposure.

Of all woodworkers, 47\% used mainly pine wood, 19\% used particle board or fibre boards (based on pine wood), and 6\% used different kinds of hard wood including beech. The rest, $28 \%$, used a mixture of different wood species.

\section{Bronchial responsiveness}

Pulmonary function tests were performed using a dry spirometer (Vitalograph, Buckingham, UK) according to ERS guidelines. ${ }^{19}$ Bronchial responsiveness was measured using the method of Yan and colleagues ${ }^{20}$ with calibrated De Vilbiss no. 40 nebulisers (Somerset, PA, USA) delivering a cumulative dose of $1.04 \mathrm{mg}$ histamine dichloride. Subjects whose $\mathrm{FEV}_{1}$ dropped by $20 \%$ or more of baseline $\mathrm{FEV}_{1}$ were considered as bronchial hyperresponsive (BHR).

\section{Atopy}

A skin prick test (double test-that is, the test for each extract was performed twice) was performed in order to evaluate immediate allergic reaction to a panel of 10 common inhalant allergens comprising grass, horse, dog, cat, house dust mite, extended with the storage mites Acarus siro and Lepidoglyphus destructor (Soluprick ALK-Abello, Copenhagen, Denmark). A positive test was defined when the mean of the longest diameter and the midpoint orthogonal diameter of the wheal was $\geqslant 3 \mathrm{~mm} \cdot{ }^{21}$ Atopy was defined as one or more positive skin prick tests.

\section{Peak flow}

All persons attending the clinical investigation were asked to perform a peak flow (PEF) monitoring; 280 (75\%) had satisfactory recordings-that is, PEF three times a day for at least two weeks. PEF recordings were performed using a Mini-Wright peak flow meter (Clement Clarke International, London, UK). Testing was performed in accordance with international guidelines, ${ }^{22}$ and the results were corrected to true flow. ${ }^{23}$ Increased PEF variability was defined as daily PEF variation $>20 \%$ or PEF period variation $>30 \%$.

\section{Bronchodilator induced reversibility (BDIR) test}

A reversibility test was carried out among subjects with a baseline $\mathrm{FEV}_{1}<60 \%$ of the predicted, and among subjects with at least a $18 \%$ decrease in $\mathrm{FEV}_{1}$ after bronchial histamine provocation $(\mathrm{n}=79)$. The subject was given five inhalations of $0.5 \mathrm{mg}$ terbutaline (Bricanyl) and $\mathrm{FEV}_{1}$ was measured after 15 minutes. A positive test (BDIR) was interpreted as an increase in $\mathrm{FEV}_{1}$ of more than $12 \%$ from baseline $\mathrm{FEV}_{1}$ and an absolute increase of more than $200 \mathrm{ml}^{24}$

\section{Diagnostic criteria of asthma}

A questionnaire based definition of asthma symptoms is given in the appendix. The definition is based on classical asthma questions (wheezing, chest tightness, coughing, self reported asthma, use of asthma drugs).

- Clinical asthma: Persons with asthma symptoms and either (1) BHR, or (2) BDIR, or (3) increased PEF variability, or (4) wheezing or chest tightness by exposure to pollen or animals.

- Work related asthma symptoms: Self assessed worsening of symptoms in relation to work, or relief of symptoms at weekends or holidays.

\section{Analyses}

Most data were analysed using SPSS statistical software (SPSS-PC for Windows, version 10.0). ${ }^{25}$ Univariate analyses were undertaken for categorical variables using $\chi^{2}$ tests. For comparisons of age and year in the industry among subjects with and without asthma symptoms, the non-parametric Kruskal-Wallis test was used. For each work task the median (geometric mean) of the individual arithmetic mean distribution was calculated. In order to compare dust level for each work task, one way analysis of variance using Sheffe's method for multiple comparisons was used. Logistic regression was used to evaluate associations between asthma and exposure. In order to correct for design effects (stratified sampling) we included a "dummy" variable for samples we did not consider when selecting cases and controls (that is, dermatitis). Exposure variables included dust exposure levels and wood species most often used. As confounders the following were included: smoking (defined as present smokers or ex-smokers for less than two years), age (five categories), previous dusty non-wood working jobs, sideline occupation, education level, and structural lung diseases (for example, tuberculosis). If the regression coefficient for the dependent variable and the exposure variable changed more than $20 \%$ when a variable was introduced, it was included in the final model. As gender and smoking are known to affect the frequency of asthma related symptoms, they were kept in the models as obligate confounders. When BHR was the outcome of interest, the results were adjusted for baseline $\mathrm{FEV}_{1}$. In order to explore the relation between dust exposure 


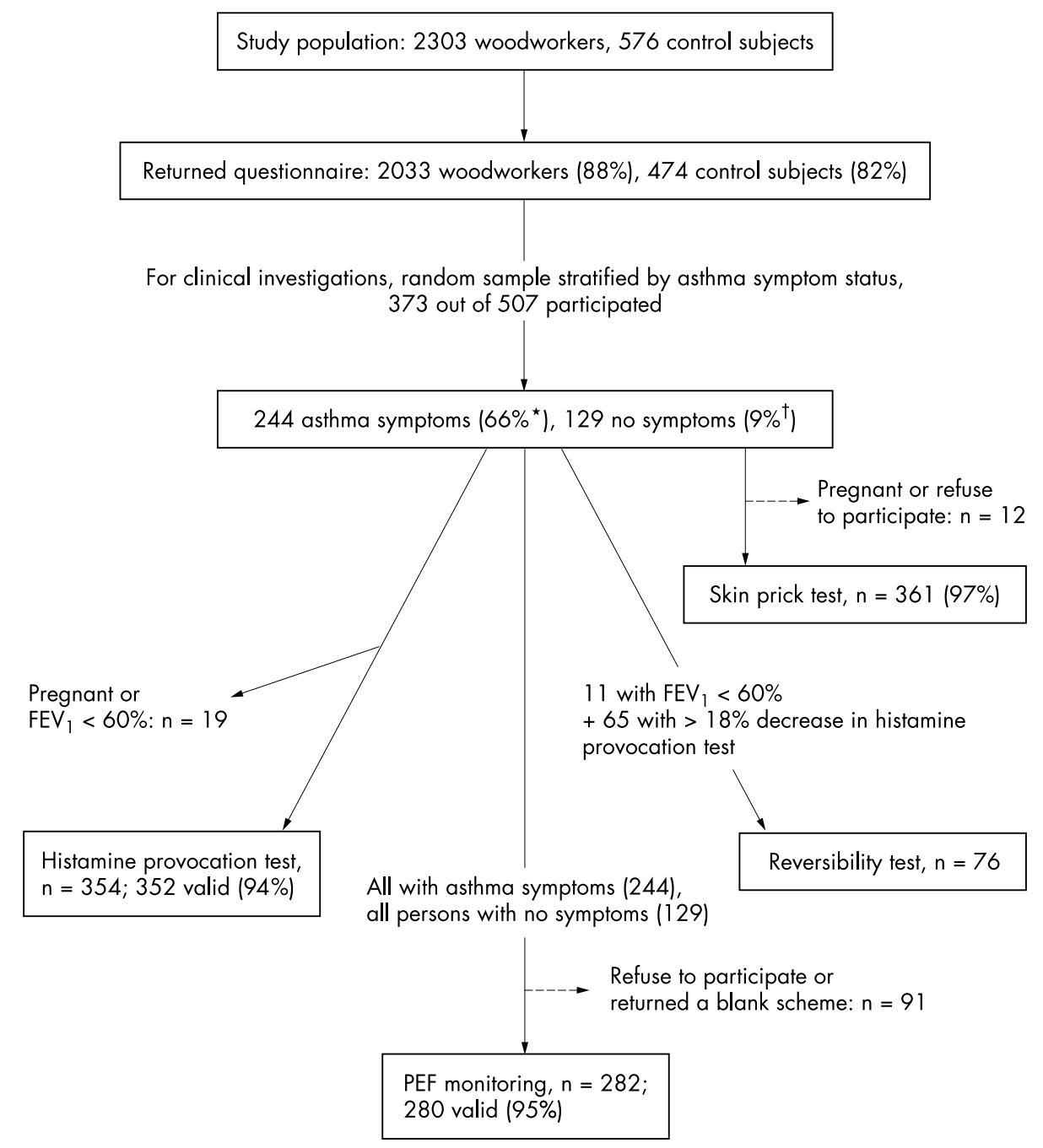

Figure 1 Flow chart of the study. *Percentage of all subjects from the cohort with asthma symptoms. †Percentage of all subjects from the cohort with no asthma or rhinitis symptoms.

and indices of asthma, general additive models (GAM) with linear regression and a log link function available in SAS software version 8 (PROC GAM) were introduced, a method earlier used in the occupational respiratory setting. ${ }^{26}$ These additive models extend a linear parametric model by allowing some or all linear functions on the predictor variables to be replaced by arbitrary smooth functions. The advantage over simple linear modelling is that the shape of an exposureresponse relation can be evaluated in greater detail, without applying a priori assumptions regarding shape. We used a GAM model, where degree of freedom (DF) could vary freely. Unless otherwise stated, the level of significance was $\mathrm{p}<0.05$, two sided.

\section{RESULTS}

Table 1 lists the demographic characteristics of the cohort. Subjects with respiratory symptoms were younger and included more heavy smokers than subjects with no respiratory symptoms. Symptomatic subjects had increased BHR and PEF variability and a larger proportion of atopics, compared to non-symptomatic subjects. No significant difference between subjects with and without asthma symptoms was seen according to wood dust exposure.

The overall GM (GSD) for 347 inhalable wood dust measurements among 234 woodworkers was 0.96 (2.02) $\mathrm{mg} / \mathrm{m}^{3}$. The GM (GSD) for inhalable dust exposure among
295 woodworkers was $0.97(1.88) \mathrm{mg} / \mathrm{m}^{3}$, range $0.17-4.10$ $\mathrm{mg} / \mathrm{m}^{3}$. The GM average exposures for the four quartiles were 0.47 (1.76), 0.88 (1.07), 1.18 (1.08), and $2.02(1.30) \mathrm{mg} / \mathrm{m}^{3}$.

Table 2 gives the exposure during a number of specific tasks. The highest exposure was found during "sanding", and the lowest exposure during "handling and assembling" and "other work tasks" (for example, work leaders).

Table 3 gives adjusted ORs for indices of asthma and risk factors among woodworkers and non-exposed subjects. No differences between the two groups were seen. Smokers were more often asthmatic, with ORs between 3.6 (1.7-7.6) (work related asthma symptoms) and 2.3 (1.0-5.4) (symptomatic BHR). In addition, atopy was strongly related to asthma, with ORs between 5.5 (2.4-13.2) (symptomatic BHR) and 3.1 (1.9-5.2) (asthma symptoms).

Statistically non-significant associations between asthma indices and dust exposure were observed among atopics (table 4), with ORs between 3.0 (0.8-11.9) (symptomatic BHR) and 1.3 (0.5-4.2) (work related asthma symptoms). Atopy and asthma were strongly associated in woodworkers (ORs between 7.4 (2.8-19.7) (symptomatic BHR) and 4.2 (2.4-7.7) (asthma symptoms)), but not in controls.

Symptomatic BHR was related to dust in a dose dependent manner, with OR $18.3(2.0-170.8)$ between the lowest and the highest exposure level (table 5). The same tendency was seen for work related asthma symptoms (OR 6.4 (1.6-26.4)), 
Table 1 Demographic characteristics of the cohort by symptom status

\begin{tabular}{|c|c|c|}
\hline & $\begin{array}{l}\text { Asthma symptoms } \\
(\mathrm{n}=244+)\end{array}$ & $\begin{array}{l}\text { No asthma symptoms } \\
(\mathrm{n}=129+)\end{array}$ \\
\hline \multicolumn{3}{|l|}{ General characteristics } \\
\hline Female, $\mathrm{n}(\%)$ & $65(26.6)$ & $32(24.8)$ \\
\hline Age, years, median (interquartile range) & $35(17.0)$ & $41(18.3)^{* *}$ \\
\hline Unskilled workers, $n$ (\%) & $114(47.3)$ & $64(51.6)$ \\
\hline Non-smokers, n (\%)§ & $67(27.8)$ & $54(43.5)^{\star *}$ \\
\hline Ex smokers, n (\%) & $24(10.0)$ & $27(21.8)^{* *}$ \\
\hline Smokers, <20/cig/day, n (\%) & $61(25.3)$ & $28(21.0)$ \\
\hline Smokers, $\geqslant 20 /$ cig/day, n (\%) & $89(36.9)$ & $17(13.7)^{\star *}$ \\
\hline \multicolumn{3}{|l|}{ Exposure characteristics } \\
\hline Woodworkers, n (\%) & $196(80.3)$ & $106(82.2)$ \\
\hline Pine\%, $n(\%) \ddagger$ & $88(45.4)$ & $51(48.6)$ \\
\hline Beech†t, n (\%) $\ddagger$ & $6(3.1)$ & $6(5.7)$ \\
\hline 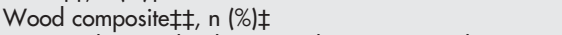 & 35 (18.0) & $23(21.9)$ \\
\hline Years in the wood industry, median (interquartile range) & $7(8.5)$ & $8(10.3)$ \\
\hline Wood dust, $<0.80 \mathrm{mg} / \mathrm{m}^{3}, \mathrm{n}(\%) \ddagger$ & $46(24.1)$ & $38(36.5)$ \\
\hline Wood dust, $0.80-0.99 \mathrm{mg} / \mathrm{m}^{3}, \mathrm{n}(\%) \ddagger$ & $37(19.4)$ & 17 (16.3) \\
\hline Wood dust, $1.00-1.39 \mathrm{mg} / \mathrm{m}^{3}, \mathrm{n}(\%) \ddagger$ & $59(30.9)$ & $29(27.9)$ \\
\hline Wood dust, $>1.39 \mathrm{mg} / \mathrm{m}^{3}, \mathrm{n}(\%) \ddagger$ & $49(25.7)$ & $20(19.2)$ \\
\hline \multicolumn{3}{|l|}{ Health characteristics } \\
\hline BHR, n (\%) & $54(23.9)$ & $3(2.4)^{\star \star}$ \\
\hline Atopy, $n(\%)$ & $130(55.3)$ & $38(30.2)^{* *}$ \\
\hline Increased PEF variation§§, n (\%) & $78(45.6)$ & $25(22.9)^{* *}$ \\
\hline \multicolumn{3}{|c|}{$\begin{array}{l}\text { †alid cases vary between variables. } \\
\text { tOnly woodworkers, } n=328 \text {. } \\
\text { \$Pearson } \chi^{2} \text { test of overall smoking status between subjects with and without asthma symptoms: } \chi^{2}=27.4 \text {, } \\
p<0.0001 \text {. } \\
\text { †Workers using mainly pine (Pinus sylvestris). } \\
+ \text { WWorkers using mainly beech. } \\
\text { t+Workers using mainly wood composite, e.g. chipboard, MDF board, etc. } \\
\text { \$\$Daily PEF variation }>20 \% \text { or PEF period variation }>30 \% \text {. } \\
* p<0.05 ;{ }^{* *} p<0.01 \text {. }\end{array}$} \\
\hline
\end{tabular}

clinical asthma (OR $3.3(1.1-10.0))$, and asthma symptoms (OR $2.3(1.0-5.6)$ ).

The association evaluated in table 5 are explored again in table 6, but now after stratification for atopy. The association between symptomatic BHR and dust level relies heavily on atopic woodworkers, where OR 22.9 (1.0-523.6) between the lowest and the highest exposure level was revealed. For work related asthma symptoms, the association with dust level was only seen for non-atopics, with OR 20.3 (1.7-244.3) between the lowest and the highest dust level.

Subjects with symptomatic BHR were characterised by an increased use of asthma medication and an increased severity in asthma symptoms compared to subjects with asthma symptoms, or clinical asthma (data not shown).

In order to explore the relation between dust level and asthma, GAM were applied as described under methods,

Table 2 Wood dust exposure as geometric mean (GM) and geometric standard deviation (GSD) of inhalable dust concentration $\left(\mathrm{mg} / \mathrm{m}^{3}\right)$ during specific work tasks

\begin{tabular}{|c|c|c|c|}
\hline & $\begin{array}{l}\text { Inhalable dust } \\
\text { GM (GSD) }\end{array}$ & $\begin{array}{l}\text { No. of } \\
\text { measurements } \\
(n=347)\end{array}$ & $\begin{array}{l}\text { No. of subjects } \\
(n=234)\end{array}$ \\
\hline Sanding & $1.46(1.68)$ & 13 & 7 \\
\hline Cutting & $1.15(1.95)$ & 108 & 79 \\
\hline $\begin{array}{l}\text { Handling and } \\
\text { assembling }\end{array}$ & $0.78(1.94)$ & 114 & 72 \\
\hline Other work tasks & $0.61(1.88)$ & 46 & 27 \\
\hline Mixed work tasks & $1.16(1.98)$ & 66 & 49 \\
\hline Total & $0.96(2.02)$ & 347 & 234 \\
\hline \multicolumn{4}{|c|}{$\begin{array}{l}\text { "Sanding" } v \text { "handling and assembly" }: p<0.05 \text {. } \\
\text { "Cutting" } v \text { "handling and assembly" and "other work tasks": } \\
p<0.05 \text {. } \\
\text { "Mixed work tasks" } v \text { "handling and assembly" and "other work tasks" } \\
p<0.05 \text {. }\end{array}$} \\
\hline
\end{tabular}

including the same confounders as in the conventional analyses. When comparing GAM and parametric linear regression (GAM without the spline function), the difference on the deviance was nearly identical for symptomatic BHR among atopics, 47.33990325 for the non-parametric and 47.33990635 for the parametric model, confirming a linear relation. The DF was 1 . The GAM estimated an 6.4 increase in OR per unit increase in dust concentration $\left(\mathrm{mg} / \mathrm{m}^{3}\right)$. A 27.2 $\left(6.4^{1.6}\right)$ increase in OR was estimated for $1.6 \mathrm{mg} / \mathrm{m}^{3}$ increase in dust concentration (the difference between low and high exposed), close to the estimate from the logistic regression analysis using categorised exposure data (OR 22.9).

For work related asthma symptoms among non-atopics, a larger difference was seen, 63.86032286 for the nonparametric and 70.93055459 for the parametric model. The DF was 2.89. The GAM estimated an 2.3 increase in OR per unit increase in dust concentration $\left(\mathrm{mg} / \mathrm{m}^{3}\right)$. An $11.4\left(2.3^{1.6}\right)$ increase in OR was estimated for $1.6 \mathrm{mg} / \mathrm{m}^{3}$ increase in dust concentration (the difference between low and high exposed), which was far from the estimate from the logistic regression analysis using categorised exposure data (OR 20.3), pointing towards a non-linear relation.

\section{DISCUSSION}

Our results suggest that atopy is an important modifier of the association between asthma and wood dust exposure, and this has, to our knowledge, not been reported before. Among atopics, symptomatic BHR was related to dust exposure in a dose dependent manner. Subjects with symptomatic BHR had an increased use of asthma medication and severe asthma symptoms compared to subjects with symptoms or clinical asthma, which may serve as an explanation for the strong association between wood dust and symptomatic BHR, but not asthma symptoms or clinical asthma. Although the results for atopic symptomatic subjects with BHR are 
Table 3 Associations between indices of asthma and risk factors among woodworkers and non-exposed subjects; OR $(95 \% \mathrm{Cl})$ in logistic regression analyses

\begin{tabular}{|c|c|c|c|c|}
\hline \multirow[b]{2}{*}{$\begin{array}{l}\text { Independent variables, } \\
0=\text { no = reference }\end{array}$} & \multicolumn{4}{|l|}{ Outcome variables } \\
\hline & $\begin{array}{l}\text { Asthma symptoms } \dagger \\
(\mathrm{n}=335)^{*}\end{array}$ & $\begin{array}{l}\text { Work related } \\
\text { asthma symptoms } \ddagger \\
(\mathrm{n}=176)^{*}\end{array}$ & $\begin{array}{l}\text { Asthma } \\
\text { symptoms + BHR§ } \\
(n=156)^{*}\end{array}$ & $\begin{array}{l}\text { Clinical asthmaब } \\
(\mathrm{n}=222)^{*}\end{array}$ \\
\hline $\begin{array}{l}\text { Wood dust exposure } \\
1 / 0 \\
\text { Smoking } 1 / 0\end{array}$ & $\begin{array}{l}1.45 \\
(0.74-2.84) \\
2.98 \\
(1.78-4.93)\end{array}$ & $\begin{array}{l}1.08 \\
(0.45-2.61) \\
3.57 \\
(1.69-7.57)\end{array}$ & $\begin{array}{l}2.16 \\
(0.72-6.52) \\
2.27 \\
(0.95-5.42)\end{array}$ & $\begin{array}{l}1.34 \\
(0.60-2.99) \\
3.23 \\
(1.77-5.90)\end{array}$ \\
\hline Atopy $1 / 0$ & $\begin{array}{l}3.10 \\
(1.87-5.16)\end{array}$ & $\begin{array}{l}3.96 \\
(1.92-8.15)\end{array}$ & $\begin{array}{l}5.52 \\
(2.40-13.16)\end{array}$ & $\begin{array}{l}3.32 \\
(1.81-6.06)\end{array}$ \\
\hline $\begin{array}{l}\text { Additional variables } \\
\text { included in the final } \\
\text { model }^{* *}\end{array}$ & Gender & $\begin{array}{l}\text { Gender, sideline } \\
\text { occupation, } \\
\text { education level }\end{array}$ & $\begin{array}{l}\text { Gender, baseline } \\
\mathrm{FEV}_{1}\end{array}$ & Gender \\
\hline
\end{tabular}

*Numbers in the final model.

†Asthma symptoms according to the appendix. Reference: no respiratory symptoms.

¥Work related wheezing or work related self reported asthma. Reference: no work related asthma symptoms.

$\S B H R+$ symptoms. Baseline $\mathrm{FEV}_{1}$ is included in the model. Reference: no asthma symptoms, no BHR.

-Persons with asthma symptoms and either (1) BHR or (2) BDIR or (3) increased PEF variability or (4) wheezing or

chest tightness by exposure to pollen or animals. Reference: no respiratory symptoms, no objective criteria

suggestive of asthma.

*All models include a "dummy" variable adjusting for the stratified sampling design.

based on a limited number of persons, which is also clear from the wide confidence intervals given in table 6, a linear relation was confirmed in more advanced smoothing analyses.

An association between work related asthma symptoms and dust concentration was found, especially among nonatopics, although further analyses using GAM did not support a straight linear relation. It is interesting that atopy acts as a risk factor for symptomatic BHR, whereas for work related asthma symptoms the relation to wood dust was observed among non-atopics. The two variables are profoundly different-that is, BHR is an objective measure for hyperresponsiveness in the lower airways, whereas work related asthma symptoms are by definition a subjective measure for the relation between symptoms and work.

The overall participating rate in the clinical investigation was $64 \%(87 \%$ answering the questionnaire $\times 74 \%$ participating in the clinical investigation), which may cause selection bias. The participation rate in the clinical study was independent of self-reported symptoms (asthma symptoms 74\%, subjects with no respiratory symptoms $71 \%$ ). Furthermore, no difference in participation rate between woodworkers and non-exposed subjects) was found (woodworkers: 76\%; controls: $72 \%$ ). ${ }^{18}$ It is thus unlikely that selection bias had any major influence on the results.

Our definition of asthma symptoms contains questions on self reported physician diagnosed asthma, asthma medication and symptoms, as outlined in the appendix. This definition has been used in other occupational asthma surveys..$^{28}$ As one of the purposes of the original study was to estimate the prevalence of asthma among woodworkers, we chose an asthma outcome with a fairly high sensitivity. When the "golden standard" was defined as BHR or bronchodilator induced reversibility or increased PEF

Table 4 Associations between indices of asthma and risk factors among woodworkers and non-exposed subjects; OR $(95 \% \mathrm{Cl})$ in logistic regression analyses; stratified by atopy and exposure

\begin{tabular}{|c|c|c|c|c|}
\hline \multirow[b]{2}{*}{$\begin{array}{l}\text { Independent variables, } \\
0=\text { no }=\text { reference }\end{array}$} & \multicolumn{4}{|c|}{ Outcome variables } \\
\hline & $\begin{array}{l}\text { Asthma } \\
\text { symptoms } \\
(\mathrm{n}=335)^{*}\end{array}$ & $\begin{array}{l}\text { Work related } \\
\text { asthma symptoms } \\
(n=176)^{*}\end{array}$ & $\begin{array}{l}\text { Asthma } \\
\text { symptoms + BHR§ } \\
(n=156)^{*}\end{array}$ & $\begin{array}{l}\text { Clinical asthma } 9 \\
(\mathrm{n}=222)^{*}\end{array}$ \\
\hline $\begin{array}{l}\text { Stratification by atopy } \\
\text { Wood dust exposure } 1 / 0 \text {, } \\
+ \text { atopy } \\
\text { Wood dust exposure 1/0, } \\
\text { - atopy }\end{array}$ & $\begin{array}{l}2.53 \\
(0.97-6.60) \\
0.84 \\
(0.33-2.12)\end{array}$ & $\begin{array}{l}1.33 \\
(0.45-4.19) \\
0.77 \\
(0.20-2.94)\end{array}$ & $\begin{array}{l}3.04 \\
(0.78-11.85) \\
1.20 \\
(0.19-7.45)\end{array}$ & $\begin{array}{l}2.00 \\
(0.70-5.76) \\
0.82 \\
(0.25-2.71)\end{array}$ \\
\hline $\begin{array}{l}\text { Stratification by exposure } \\
\text { Atopy } 1 / 0 \text {, woodworkers }\end{array}$ & $\begin{array}{l}4.23 \\
(2.37-7.65) \\
0.98\end{array}$ & $\begin{array}{l}4.79 \\
(2.06-11.11) \\
1.78\end{array}$ & $\begin{array}{l}7.44 \\
(2.80-19.72) \\
2.13\end{array}$ & $\begin{array}{l}4.41 \\
(2.19-8.87) \\
1.01\end{array}$ \\
\hline $\begin{array}{l}\text { subjects } \\
\text { lath }\end{array}$ & $(0.33-2.89)$ & $(0.40-7.94)$ & $(0.25-17.87)$ & $(0.27-3.84)$ \\
\hline
\end{tabular}

Variables included in the final models are identical to those stated in table 3.

*Numbers in the final model.

†Asthma symptoms according to the appendix. Reference: no respiratory symptoms.

$\ddagger$ Work related wheezing or work related self reported asthma. Reference: no work related asthma symptoms. $\S B H R+$ symptoms. Baseline $\mathrm{FEV}_{1}$ is included in the model. Reference: no asthma symptoms, no BHR.

-Persons with asthma symptoms and either (1) BHR or (2) BDIR or (3) increased PEF variability or (4) wheezing or chest tightness by exposure to pollen or animals. Reference: no respiratory symptoms, no objective criteria suggestive of asthma. 
Table 5 Associations between indices of asthma and risk factors among woodworkers; OR $(95 \% \mathrm{Cl})$ in logistic regression analyses

\begin{tabular}{|c|c|c|c|c|}
\hline \multirow[b]{2}{*}{ Independent variables } & \multicolumn{4}{|l|}{ Outcome variables } \\
\hline & $\begin{array}{l}\text { Asthma } \\
\text { symptoms } † \\
(\mathrm{n}=247)^{*}\end{array}$ & $\begin{array}{l}\text { Work related } \\
\text { asthma } \\
\text { symptomsł } \\
(n=136)^{*}\end{array}$ & $\begin{array}{l}\text { Asthma } \\
\text { symptoms + BHR§ } \\
(n=118)^{*}\end{array}$ & $\begin{array}{l}\text { Clinical asthmaq } \\
(n=181)^{*}\end{array}$ \\
\hline $\begin{array}{l}\text { Wood dust, } 0.80-0.99 \mathrm{mg} / \mathrm{m}^{3} \text {, } \\
\text { ref. }<0.80 \\
\text { Wood dust, } 1.0-1.39 \mathrm{mg} / \mathrm{m}^{3} \text {, } \\
\text { ref }<0.80 \\
\text { Wood dust, }>1.39 \mathrm{mg} / \mathrm{m}^{3} \text {, } \\
\text { ref }<0.80 \\
\text { Smoking, } 1 / 0, \text { reference }=\text { no } \\
\text { smoking } \\
\text { Atopy, } 1 / 0 \text {, reference = no atopy } \\
\text { Additional variables included } \\
\text { in the final model }{ }^{\star *}\end{array}$ & $\begin{array}{l}1.27 \\
(0.52-3.08) \\
1.22 \\
(0.53-2.82) \\
2.30 \\
(0.95-5.56) \\
3.25 \\
(1.75-6.06) \\
5.01 \\
(2.60-9.67) \\
\text { Gender, sideline } \\
\text { occupation, } \\
\text { previous dusty } \\
\text { non-woodworking } \\
\text { jobs }\end{array}$ & $\begin{array}{l}3.61 \\
(0.83-15.72 \\
2.05 \\
(0.47-9.03) \\
6.43 \\
(1.57-26.43) \\
4.13 \\
(1.55-11.02) \\
7.24 \\
(2.59-20.28) \\
\text { Gender, age, } \\
\text { education level, } \\
\text { sideline } \\
\text { occupation }\end{array}$ & $\begin{array}{l}5.68 \\
(0.62-51.64) \\
3.81 \\
(0.49-33.20) \\
18.30 \\
(1.96-170.77) \\
3.81 \\
(1.11-13.07) \\
18.71 \\
(4.78-73.25) \\
\text { Gender, age, } \\
\text { sideline occupation, } \\
\text { beech, baseline } \\
\mathrm{FEV}_{1}\end{array}$ & $\begin{array}{l}2.08 \\
(0.68-6.37) \\
2.01 \\
(0.73-5.53) \\
3.29 \\
(1.09-9.96) \\
4.01 \\
(1.87-8.62) \\
5.24 \\
(2.38-11.53) \\
\text { Gender, sideline } \\
\text { occupation, } \\
\text { previous dusty } \\
\text { non-woodworking } \\
\text { jobs }\end{array}$ \\
\hline \multicolumn{5}{|c|}{$\begin{array}{l}\text { *Numbers in the final model. } \\
\text { †Asthma symptoms according to the appendix. Reference: no respiratory symptoms. } \\
\text { fWork related wheezing or work related self reported asthma. Reference: no work related asthma symptoms. } \\
\text { SBHR + symptoms. Baseline FEV } 1 \text { is included in the model. Reference: no asthma symptoms, no BHR. } \\
\text {-Persons with asthma symptoms and either (1) BHR or (2) BDIR or (3) increased PEF variability or (4) wheezing or } \\
\text { chest tightness by exposure to pollen or animals. Reference: no respiratory symptoms, no objective criteria } \\
\text { suggestive of asthma. } \\
\text { *A All models include a "dummy" variable adjusting for the stratified sampling design. }\end{array}$} \\
\hline
\end{tabular}

variability, the sensitivity of asthma symptoms as defined in this study was $75 \%$, with a specificity of $61 \%$. Physician diagnosed asthma had an $85 \%$ specificity, but the sensitivity was low, 33\%. ${ }^{18}$ The high specificity and low sensitivity found for physician diagnosed asthma confirms results from several studies as reviewed by Torén and colleagues. ${ }^{29}$ As a consequence, physician diagnosed asthma as definition will seriously underestimate the frequency of asthma. As noncases in this study are defined as subjects with no asthma symptoms, it is not probable that "true" cases are misclassified as non-cases.

The furniture industry is affected by short duration of employment; for example, in our study, $20 \%$ of the woodworkers have only been employed one year or less at their present workplace. ${ }^{18}$ Consequently, a cross-sectional study design will tend to underestimate the effects of wood dust. Another problem with cross-sectional studies is the "healthy worker effect", which will also tend to underestimate the risk of health effects among exposed subjects. We have earlier revealed a negative association between coughing, chronic bronchitis, and wheezing on the one hand and seniority in the wood industry on the other, after controlling for age, indicating a selection away from the industry. ${ }^{16} \mathrm{~A}$ high frequency of coughing and hay fever among controls with previous employment in the wood industry ${ }^{16}$ could also be an indication of "healthy worker effect".

The revealed dose-response relation between wood dust exposure and symptomatic BHR indicates a possible causal relation. However, the analyses follow a nested case-referent design, based on stratification by asthma symptom status from the base cross-sectional study. Since the time sequence of events-wood dust exposure leading to asthma - can only be studied by following a group of woodworkers over time,

Table 6 Associations between indices of asthma and risk factors among woodworkers; OR $(95 \% \mathrm{Cl})$ in logistic regression analyses, stratified by atopy

\begin{tabular}{|c|c|c|c|c|}
\hline Stratification by atopy & $\begin{array}{l}\text { Asthma symptoms } \\
(n=247)^{*}\end{array}$ & $\begin{array}{l}\text { Work related } \\
\text { asthma symptoms } \\
(\mathrm{n}=136)^{*}\end{array}$ & $\begin{array}{l}\text { Asthma } \\
\text { symptoms + BHR } \\
(n=118)^{*}\end{array}$ & $\begin{array}{l}\text { Clinical asthma } \\
(n=181)^{*}\end{array}$ \\
\hline \multicolumn{5}{|l|}{ + atopy } \\
\hline $\begin{array}{l}\text { Wood dust, } 0.80-0.99 \\
\mathrm{mg} / \mathrm{m}^{3} \text {, ref. }<0.80\end{array}$ & $\begin{array}{l}2.33 \\
(0.58-9.33)\end{array}$ & $\begin{array}{l}1.91 \\
(0.20-18.38)\end{array}$ & $\begin{array}{l}8.69 \\
(0.47-159.82)\end{array}$ & $\begin{array}{l}2.40 \\
(0.47-12.33)\end{array}$ \\
\hline Wood dust, $1.0-1.39 \mathrm{mg} / \mathrm{m}^{3}$, & 1.96 & 0.53 & 3.50 & 2.27 \\
\hline ref. $<0.80$ & $(0.56-6.81)$ & $(0.04-7.23)$ & $(0.19-64.96)$ & $(0.53-9.64)$ \\
\hline Wood dust, $>1.39 \mathrm{mg} / \mathrm{m}^{3}$, & 2.87 & 1.48 & 22.94 & 1.65 \\
\hline ref. $<0.80$ & $(0.59-13.83)$ & $(0.10-21.44)$ & $(1.01-523.57)$ & $(0.29-9.44)$ \\
\hline \multicolumn{5}{|l|}{ - atopy } \\
\hline Wood dust, $0.80-0.99$ & 0.83 & 6.72 & 2.32 & 1.60 \\
\hline $\mathrm{mg} / \mathrm{m}^{3}$, ref. $<0.80$ & $(0.25-2.73)$ & $(0.51-89.22)$ & (0.04-149.82) & $(0.31-8.28)$ \\
\hline Wood dust, $1.0-1.39 \mathrm{mg} / \mathrm{m}^{3}$, & 0.93 & 6.83 & 4.50 & 1.75 \\
\hline ref. $<0.80$ & $(0.30-2.91)$ & (0.44-105.49) & $(0.04-456.70)$ & $(0.40-7.63)$ \\
\hline Wood dust, $>1.39 \mathrm{mg} / \mathrm{m}^{3}$, & 2.04 & 20.25 & 2.50 & 4.28 \\
\hline ref. $<0.80$ & $(0.70-5.97)$ & (1.68-244.33) & (0.02-292.61) & $(1.00-18.31)$ \\
\hline
\end{tabular}


our findings need further confirmation in a prospective study.

Because of the design of the study (stratified sampling based on symptom status), analyses using other endpoints could lead to biased results. As a consequence, we have chosen to compare subjects by symptom status and not by exposure status.

In order to increase precision in the exposure assessment we used individual measurements for the majority of woodworkers. Due to day to day variability in exposure, individual exposure assessment strategies usually lead to decreases of the slope of the "true" relation (attenuation) between exposure and health effect, unless several repeated measurements are performed. We have previously estimated a $50 \%$ attenuation using one measurement and 25\% attenuation using three repeated measurements for each worker, using the ratio of within to between workers variability estimated in this study. ${ }^{30}$ Hence, our results are at most $50 \%$ attenuated. We have previously shown that the between factory variance in dust exposure and the contrast in exposure level among factories was low. ${ }^{30}$ As a consequence, we did not include factory in the analyses. The overall dust level was low, compared to earlier studies in the furniture industry. ${ }^{31-33}$ Despite this, we found associations between indices of asthma and wood dust exposure.

There was a 2-18 month time lag between the exposure assessment and the clinical examination. Despite this, we found dose-response relations between symptomatic BHR and exposure, suggesting BHR to be related to average current exposure rather than acute exposure. Bohadana and colleagues ${ }^{3}$ have recently described a dose dependent relation between BHR and beech dust, with a median cumulative beech dust exposure of 110 years * $\mathrm{mg} / \mathrm{m}^{3}$, suggesting the cumulative wood dust exposure to be a determinant for BHR. In our investigation, no relation between seniority in the wood industry and indices of asthma was revealed.

Talini and colleagues ${ }^{7}$ investigated 296 furniture workers and found 18\% with BHR, with no difference between assemblers and workers processing wood. In our study, the exposure ratio between assembly workers and woodworkers processing wood was approximately 0.6 (table 2 , sanding and cutting $v$ assembling), highlighting the problem using assemblers as a control group.

One follow up study among 125 subjects with western red cedar asthma concluded that atopy was not a risk factor, ${ }^{34}$ which is not in agreement with our results. For western red cedar, a low molecular weight compound, plicatic acid, is responsible, and both non-immunological and immunological mechanisms are involved. ${ }^{13}$ For other wood species, the mechanism is almost unknown. Specific sensitisation for different species has been reported, but type I allergy is not suspected to be a major cause of wood dust induced asthma. ${ }^{13}$ Atopy is a known risk factor for specific sensitisation to high molecular occupational allergens such as wheat flour ${ }^{35}$ and animal dander, ${ }^{36}$ but is has also been documented that atopy in combination with the nonallergenic inflammatory endotoxin is a risk factor for asthma symptoms among pig farmers, ${ }^{37}$ pointing towards atopy as a possible mediator for asthma related to non-allergenic exposures.

Animal studies have shown that abietic acid, the major constituent in pine resin, can produce lytic damage to alveolar, tracheal, and bronchial epithelial cell, ${ }^{38}$ and it has been associated with occupational asthma in other industries. ${ }^{39}$ In this study, the content of abietic acid in pine was not analysed. Terpenes, a naturally occurring substance in pine and other coniferous trees, have been documented to cause irritation to mucous membranes ${ }^{40}$ and increased bronchial responsiveness. ${ }^{41}$ During the processing of pine, terpenes are potentially liberated, although we found low levels of terpenes in our investigation..$^{42}$ Other potential relevant exposures are endotoxin, fungal $\beta(1,3)$-glucans, and mould spores, ${ }^{43-45}$ which have been associated with respiratory health effects among saw mill workers. ${ }^{6}{ }^{45}$ Although most pronounced in saw mill and logging sites, woodworkers processing dry wood may also be exposed to biohazards. ${ }^{44}$

Processing plywood and fibre board may cause exposure to formaldehyde, ${ }^{46}$ and asthma symptoms among woodworkers exposed to formaldehyde alone or in combination with wood dust have been documented ${ }^{47}$ A health based recommended occupational exposure limit of $0.10 \mathrm{ppm}\left(0.13 \mathrm{mg} / \mathrm{m}^{3}\right)$ has been recommended in the Netherlands. ${ }^{48}$ In a Danish study, the mean formaldehyde level among furniture workers using glue capable of emitting formaldehyde vapours was $0.15 \mathrm{mg} / \mathrm{m}^{3},{ }^{49}$ and the formaldehyde concentration in particle boards and glue has been decreasing during the past 10 years (Møller, personal communication).

Not surprisingly, there was an increased frequency of respiratory impairment among smokers. We have in earlier analyses documented an increased effect of wood dust among non-smokers and among females, ${ }^{16}$ which was not the case in the present analyses.

Respiratory impairment seems to occur at levels well below the current occupational exposure limit for wood dust, for example, $2 \mathrm{mg} / \mathrm{m}^{3}$ in Denmark and the Netherlands, and $5 \mathrm{mg} / \mathrm{m}^{3}$ for many other countries, for instance the USA. This finding supports recommendations by Demers and colleagues $^{50}$ to lower the current standard for wood dust exposure.

In conclusion, we found, despite a low dust level, a tendency towards increased asthma among atopic woodworkers compared to atopic non-exposed subjects.

Asthma was related to dust level, most pronounced for symptomatic BHR among atopics. For work related asthma symptoms the association with dust level was seen only for non-atopics.

We found strong associations between atopy and asthma among woodworkers, but not among non-exposed subjects.

\section{ACKNOWLEDGEMENTS}

The study was supported by The Danish Work Environment Foundation; Viborg County; The Danish Medical Research Council; The Wood Industry and Building Workers Union in Denmark; The Danish Lung Association; The Asthma and Allergy Association; and The Health Insurance Fund.

\section{Authors' affiliations}

V Schlünssen, I Schaumburg, Department of Occupational and Environmental Medicine, Skive Hospital, DK 7800 Skive, Denmark D Heederik, Institute for Risk Assessment Sciences (IRAS), Division of Environmental and Occupational Health, Utrecht University, NL 3512 Utrecht, Netherlands

E Taudorf, Department of Respiratory Medicine, Aalborg Hospital, 9200 Aalborg SV, Denmark

T Sigsgaard, Department of Environmental and Occupational Medicine, University of Aarhus, DK 8000 Aarhus C, Denmark

\section{APPENDIX: QUESTIONNAIRE BASED ASTHMA DEFINITION}

Table Al lists asthma questions included in the questionnaire. Asthma symptoms ${ }^{27}$ are considered present if the subjects answers yes to at least one group A question and two or more group $\mathrm{B}$ questions or at least two group $\mathrm{A}$ questions. 
Table Al Asthma questions included in the questionnaire

Group A Group B

Have you been told by a doctor that you have asthma?

Do you have asthma? Have you ever had asthma? Do you ever wheeze?

Do

Do you ever have chest tightness? Do you wake in the night with chest tightness?

Do you cough when you wake up in

the morning?

Do you wake up because of

coughing?

Do you wheeze because of

exposure to cold air?

Do you wheeze when you exercise?

Do you wheeze because of

exposure to pollen?

Do you wheeze because of

exposure to animals?

Do you use asthma drugs?
Do you wake in the night wheezing?

\section{REFERENCES}

1 Kauppinen T, Toikkanen J, Pedersen D, et al. Occupational exposure to carcinogens in the European Union. Occup Environ Med 2000;57:10-18.

2 Ordman D. Wood dust as an inhalant allergen. S Afr Med J 1949;23:973-5.

3 Bohadana AB, Massin N, Wild P, et al. Symptoms, airway responsiveness, and exposure to dust in beech and oak wood workers. Occup Environ Med 2000;57:268-73.

4 Åhman M, Söderman E, Cynkier I, et al. Work-related respiratory problems in industrial arts teachers. Int Arch Occup Environ Health 1995;67:111-18.

5 Shamssain MH. Pulmonary function and symptoms in workers exposed to wood dust. Thorax 1992:47:84-7.

6 Mandryk J, Alwais KU, Hocking AD. Work-related symptoms and doseresponse relationships for personal exposures and pulmonary function among woodworkers. Am J Ind Med 1999;35:481-90.

7 Talini D, Monteverdi A, Benvenuti A, et al. Asthma-like symptoms, atopy, and bronchial responsiveness in furniture workers. Occup Environ Med 1998;55:786-91.

8 Douwes J, McLean D, Slater T, et al. Asthma and other respiratory symptoms in New Zealand pine processing sawmill workers. Am J Ind Med 2001;38:608-15.

9 Hessel PA, Herbert FA, Melenka LS, et al. Lung health in sawmill workers exposed to pine and spruce. Chest 1995;108:642-6.

10 Chan-Yeung M, Vedal S, Kus J, et al. Symptoms, pulmonary function, and bronchial hyperreactivity in western red cedar workers compared with those in office workers. Am Rev Respir Dis 1984;130:1038-41.

11 Whitehead LW, Ashikaga T, Vacek P. Pulmonary function status of workers exposed to hardwood or pine dust. Am Ind Hyg Assoc J 1981;42:178-86.

12 Hausen BM. Woods injurious to human health. A manual. Berlin; New York. Walter de Gruyter, 1981.

13 Chan-Yeung $M$. Western red cedar (Tjuja Plicata) and other wood dust. In: Bernstein IL, Chan-Yeung M, Malo JL, Bernstein DI, eds. Asthma in the workplace. New York; Basel; Hong Kong: Marcel Dekker, 1999:543-64.

14 Vinzents PS. A passive personal dust monitor. Ann Occup Hyg 1996:40:261-80.

15 Schlünssen V, Vinzents PS, Mikkelsen AB, Schaumburg I. Wood dust exposure in the Danish furniture industry using conventional and passive monitors. Ann Occup Hyg $2001 ; 45: 157-64$.

16 Schlünssen V, Schaumburg I, Taudorf E, et al. Respiratory symptoms and lung function among Danish woodworkers. J Occup Environ Med 2002;44:82-98.

17 American Thoracic Society, Ferris BG. Epidemiology standardization project. Am Rev Respir Dis 1978;118(6, part 2):1-120.

18 Schlünssen V. Asthma and other respiratory diseases among workers in the furniture industry occupationally exposed to wood dust. Thesis. Department of Occupational and Environmental Medicine, Skive Hospital and Department of Environmental and Occupational Medicine, University of Aarhus, 2001.

19 Quanjer PH, Tammeling GJ, Cotes JE, et al. Lung volumes and forced ventilatory flows. Report Working Party Standardization of Lung Function Tests, European Community for Steel and Coal. Official Statement of the European Respiratory Society. Eur Respir J Suppl 1993;16:5-40.

20 Yan K, Salome C, Woolcock AJ. Rapid method for measurement of bronchial responsiveness. Thorax 1983;38:760-5.

21 Dreborg S, Frew A, Bousquet J, et al. Allergen standardization and skin test. Allergy 1993;48(14):48-82.
22 Quanjer PH, Lebowitz MD, Gregg I, et al. Peak expiratory flow: conclusions and recommendations of a Working Party of the European Respiratory Society. Eur Respir J Suppl 1997;24:2S-8S.

23 Pedersen O F, Rasmussen T R, Omland $\varnothing$, et al. Peak expiratory flow and the resistance of variable orifice type peak flow meters. Eur Respir $J$ 1996;9:828-33.

24 American Thoracic Society. Lung function testing: selection of reference values and Interpretative Strategies. Am Rev Respir Dis 1991;144:1202-18.

25 SPSS. Base 10.0 syntaks reference guide. Chicago, IL: SPSS Inc., 1999

26 Heederik D, Houba R. An exploratory quantitative risk assessment for high molecular weight sensitizers: wheat flour. Ann Occup Hyg 2001;45:175-85.

27 Sigsgaard T, Hjort C, Omland $\varnothing$, et al. Respiratory health and allergy among young farmers and non farming rural mails in Denmark: the SUS study. Journal of Agro Medicine 1997;4(1/2):63-78.

28 Omland $\varnothing$, Sigsgaard T, Hiort C, et al. Lung status in young Danish rurals: the effect of farming exposure on asthma-like symptoms and lung function. Eur Respir J 1999;13:31-7.

29 Toren K, Brisman J, Jarvholm B. Asthma and asthma-like symptoms in adults assessed by questionnaires. A literature review. Chest 1993;104:600-8.

30 Vinzents PS, Schlünssen V, Feveile H, et al. Variation in exposure to inhalable wood dust in the Danish furniture industry. Within- and between-workers and factory components estimated from passive dust sampling. Ann Occup Hyg 2001;45:603-8.

31 Scheeper B, Kromhout H, Boleii JS. Wood-dust exposure during woodworking processes. Ann Occup Hyg 1995;39:141-54.

32 Vinzents PS, Laursen B. A national cross-sectional study of the working environment in the Danish wood and furniture industry-air pollution and noise. Ann Occup Hyg 1993;37:25-34.

33 Alwis U, Mandryk J, Hocking AD, et al. Dust exposures in the wood processing industry. Am Ind Hyg Assoc J 1999;60:641-6.

34 Chan-Yeung M, Lam S, Koener S. Clinical features and natural history of occupational asthma due to western red cedar (Thuja plicata). Am J Med 1982;72:411-15

35 Houba R, Heederik D, Doekes G. Wheat sensitization and work-related symptoms in the baking industry are preventable. An epidemiologic study. Am J Respir Crit Care Med 1998;158(5 pt 1):1499-503.

36 Hollander A, Doekes G, Heederik D. Cat and dog allergy and total lgE as risk factors of laboratory animal allergy. J Allergy Clin Immunol 1996;98:545-54.

37 Preller L, Doekes G, Heederik D, et al. Exposure to disinfectant and endotoxins in relation to atopic sensitisation and symptoms consistent with asthma. Eur Respir J 1996;9:1407-13.

38 Ayars GH, Altman LC, Frazier CA, et al. The toxicity of constituents of cedar and pine woods to pulmonary epithelium. J Allergy Clin Immunol 1989:83:610-18.

39 Sadhra S, Foulds IS, Gray CN, et al. Colophony-uses, health effects, airborne measurements analysis. Ann Occup Hyg 1994;38:385-96.

40 Kasanen J-P, Pasanen A-L, Pasanen $P$, et al. Evaluation of sensory irritation of (delta) ${ }^{3}$-carene and turpentine, and acceptable levels of monoterpenes in occupational and indoor environment. J Toxicol Environ Health 1999;56(part A):89-114.

41 Malmberg PO, Rask-Andersen A, Larsson KA, et al. Increased bronchial responsiveness in workers sawing Scots pine. Am J Respir Crit Care Med 1996;153:948-52

42 Mikkelsen AB, Schlünssen V, Schaumburg I. Exposure to terpenes in the Danish furniture industry [abstract]. 46 Nordiska Arbetsmiliømötet, Reykjavik, Iceland, 1998.

43 Douwes J, Mclean D, van Der Maarl E, et al. Worker exposures to airborne dust, endotoxin and beta $(1,3)$-glycan in two New Zealand sawmills. Am J Ind Med 2000;38:426-30.

44 Alwis U, Mandryk J, Hocking AD. Exposure to biohazards and wood dust: bacteria, fungi, endotoxins, and (1->3) beta-D-glucans. Appl Occup Environ Hyg 1999;14:598-608.

45 Eduard W, Sandven P, Levy F. Exposure and lgG antibodies to mold spores in wood trimmers: exposure-response relationships with respiratory symptoms. Appl Occup Environ Hyg 1994;9:44-8.

46 Kauppinen TP, Niemela RI. Occupational exposure to chemical agents in the particleboard industry. Scand J Work Environ Health 1985;11:357-63.

47 Holmstrom M, Wilhelmsson B. Respiratory symptoms and pathophysiological effects of occupational exposure to formaldehyde and wood dust. Scand J Work Environ Health 1988;14:306-11.

48 Dutch Expert Committee on Occupational Standards. Health-based recommended occupational exposure limit for formaldehyde. WGD 99-44. Health Council of the Netherlands, 1999.

49 Hansen PM, Schultz K, Arbejdstilsynet. Træstøv: en pilotundersøgelse foretaget i træindustrien. København: Arbejdstilsynet, 1888 (in Danish).

50 Demers PA, Teschke K, Kennedy SM. What to do about softwood? A review of respiratory effects and recommendations regarding exposure limits. Am J Ind Med 1997;31:385-98. 